\title{
Electrochemical and spectroscopic characterisation of amphetamine-like drugs: Application to the screening of 3,4-methylenedioxymethamphetamine (MDMA) and its synthetic precursors
}

\author{
Nuno Milhazes $^{\text {a,b,c }}$, Pedro Martins ${ }^{\mathrm{d}}$, Eugenio Uriarte ${ }^{\mathrm{d}}$, Jorge Garrido ${ }^{\mathrm{e}, \mathrm{f}}$, \\ Rita Calheiros $^{\mathrm{e}}$, M. Paula M. Marques ${ }^{\mathrm{e}, \mathrm{g}}$, Fernanda Borges ${ }^{\mathrm{b}, \mathrm{e}, *}$ \\ ${ }^{a}$ CEQOFFUP, Faculdade de Farmácia, Universidade do Porto, Portugal \\ ${ }^{\mathrm{b}}$ Departamento de Química Orgânica, Faculdade de Farmácia, Universidade do Porto, Portugal \\ c Instituto Superior de Ciências da Saúde-Norte, Gandra, Paredes, Portugal \\ ${ }^{\mathrm{d}}$ Departamento de Química Orgánica, Facultade de Farmacia, Universidad de Santiago de Compostela, Spain \\ e Unidade I\&D "Química-Física Molecular", Portugal \\ ${ }^{\mathrm{f}}$ Departamento de Engenharia Química, ISEP, Instituto Politécnico do Porto, Portugal \\ ${ }^{\mathrm{g}}$ Departamento de Bioquímica, Faculdade de Ciências e Tecnologia, Universidade de Coimbra, Portugal
}

Received 5 January 2007; received in revised form 5 June 2007; accepted 14 June 2007

Available online 19 June 2007

\begin{abstract}
A complete physicochemical characterisation of MDMA and its synthetic precursors MDA, 3,4-methylenedioxybenzaldehyde (piperonal) and 3,4-methylenedioxy- $\beta$-methyl- $\beta$-nitrostyrene was carried out through voltammetric assays and Raman spectroscopy combined with theoretical (DFT) calculations. The former provided important analytical redox data, concluding that the oxidative mechanism of the $N$-demethylation of MDMA involves the removal of an electron from the amino-nitrogen atom, leading to the formation of a primary amine and an aldehyde. The vibrational spectroscopic experiments enable to afford a rapid and reliable detection of this type of compounds, since they yield characteristic spectral patterns that lead to an unequivocal identification.

Moreover, the rational synthesis of the drug of abuse 3,4-methylenedioxymethamphetamine (MDMA or "ecstasy") from one of its most relevant precursors 3,4-methylene-dioxyamphetamine (MDA), is reported. In addition, several approaches for the $N$-methylation of MDA, a limiting synthetic step, were attempted and the overall yields compared.
\end{abstract}

(C) 2007 Elsevier B.V. All rights reserved.

Keywords: 3,4-Methylenedioxymethamphetamine; Synthesis; Raman spectroscopy; Voltammetry; Density functional theory calculations

\section{Introduction}

The amphetamine analogues 3,4-methylenedioxymethamphetamine (MDMA, "ecstasy") and 3,4-methylenedioxyamphetamine (MDA) are popular recreational drugs mainly due to their stimulant effects on the central nervous system and increased sense of well being [1-4]. These compounds are ring-substituted phenethylamines, structurally related to both psychomotor stimulant amphetamines and the hallucino-

\footnotetext{
* Corresponding author at: Departamento de Química Orgânica, Faculdade de Farmácia, Universidade do Porto, 4050-047 Porto, Portugal. Tel.: +351 222078900; fax: +351222003977.

E-mail address: fborges@ff.up.pt (F. Borges).
}

gen mescaline. MDMA is nowadays a commonly misused drug, thus giving rise to a serious public health problem repeatedly associated with serotoninergic neurotoxicity [4-6].

All methylenedioxy-containing amphetamines became very popular after modification of the MDA structure in clandestine laboratories, by replacement of one or two hydrogens in the nitrogen atom by alkyl groups, yielding several distinct compounds with high potential for abuse. In fact, the simple addition of a $N$-methyl group is responsible for a decrease in the temporal course of action of the drug to less than half, as well as for a reduction (or even a disappearance) of the hallucinogenic effects associated to MDA [1].

MDA, besides other compounds, is frequently described as an impurity in the MDMA synthetic process. It is also produced 


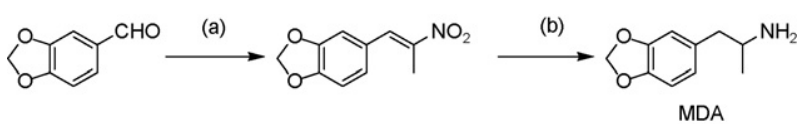

Fig. 1. General procedure for the synthesis of MDA. Chemical conditions: (a) EtNO ${ }_{2}, \mathrm{NH}_{4} \mathrm{CH}_{3} \mathrm{COO}$, reflux; (b) $\mathrm{LiAlH}_{4}$, THF, reflux.

metabolically by $N$-demethylation of MDMA, hence becoming its major metabolite in a short time after ingestion. This biotransformation step is thought to proceed through a carbinolamine intermediate, formed by cytochrome P-450 mediated oxidation of the $\alpha$-carbon to the $N$-methyl group, or through $N$-oxidation followed by rearrangement to a primary amine [7,8]. Accordingly, the knowledge of conceptual biotransformation, in which oxidation reactions play a major role [9], is absolutely critical to understand the toxicity of this kind of compounds.

The present work reports the total synthesis of MDA and MDMA. Firstly, the preparation of MDA was based on a wellknown synthetic procedure, often described in the literature as one of the main routes for the manufacture of amphetamines [10-12], that relies upon the synthesis of the appropriate $\beta$-methyl- $\beta$-nitrostyrene precursor (Fig. 1). Secondly, several different pathways for $N$-methylation of MDA were investigated (Fig. 2), since this step is known to be limiting.

The oxidative electroactivity of MDMA and its synthetic precursors MDA, 3,4-methylenedioxybenzaldehyde (piperonal) and 3,4-methylenedioxy- $\beta$-methyl- $\beta$-nitrostyrene (Fig. 1) was studied using voltammetric techniques. Besides the putative analytical interest, the results thus gathered can hopefully help to clarify the hypothetical in vivo $\mathrm{N}$-demethylation oxidation process. Actually, MDMA metabolism is known to comprise one or more oxidative pathways [13].

Furthermore, a conformational characterisation of MDMA and MDA was carried out through Raman spectroscopic experiments combined to quantum mechanical (DFT) calculations. Although there are some reported studies on the Raman analysis of amphetamine-like compounds [14-21], these experiments have only focused on particular regions of the vibrational spectra.

\section{Experimental}

\subsection{Chemicals}

Ethyl formate, lithium aluminium hydride (1 $\mathrm{M}$ solution in THF), pyridine, trifluoroacetic anhydride, formaldehyde (37\% solution in water), sodium cyanoborohydride, sodium hydride (60\% dispersion in mineral oil), methyl iodide, ethyl chloroformate, cesium carbonate and all the dry solvents were purchased from Sigma-Aldrich Química S.A. (Sintra, Portugal). All other reagents and solvents (pro analysis grade) were acquired from Merck (Lisbon, Portugal). All reagents were used without further purification. Deionised water (conductivity $<0.1 \mu \mathrm{S} \mathrm{cm}^{-1}$ ) was used in all experiments.

\subsection{Synthesis}

\subsubsection{Structural elucidation}

${ }^{1} \mathrm{H}$ and ${ }^{13} \mathrm{C}$ NMR data were acquired, at room temperature, on a Brüker AMX 300 spectrometer operating at 300.13 and $75.47 \mathrm{MHz}$, respectively. Dimethylsulfoxide- $d_{6}$ was used as a solvent; chemical shifts being expressed in $\delta$ (ppm) values relative to tetramethylsilane (TMS) (as internal reference); coupling constants $(J)$ are in Hz. Spectral assignments were also made from DEPT (Distortionless Enhancement by Polarization Transfer) experiments (italicised values). Electron impact mass spectra (EI-MS) were obtained on a VG AutoSpec instrument; data are reported as $\mathrm{m} / \mathrm{z}$ (\% of relative intensity for the most important fragments). Melting points were measured on a Köfler microscope (Reichert Thermovar) and are uncorrected. All the intermediates of the following syntheses were identified by mass spectroscopy and were found to be the described compounds.

\subsubsection{Chromatographic conditions}

The analytical control was performed by thin-layer chromatography (TLC) on plates precoated with silica gel $60 \mathrm{~F}_{254}$ as stationary phase $(0.2 \mathrm{~mm}$ as layer thickness $)$ and the following mobile phases: petroleum ether/diethyl ether/formic

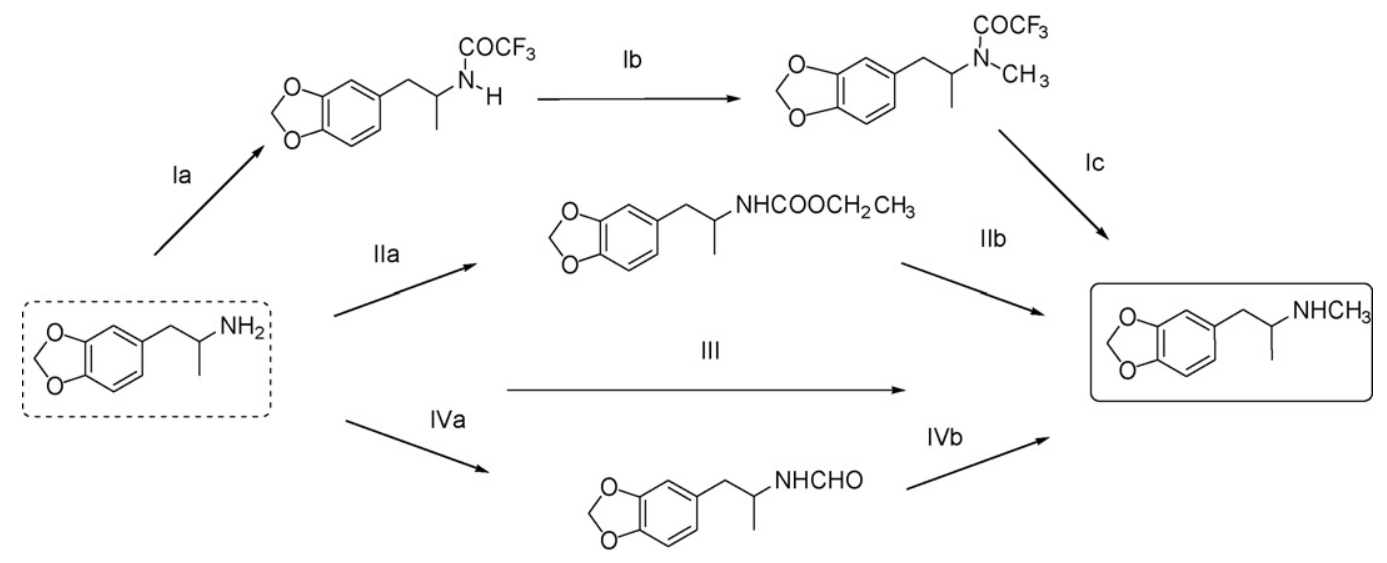

Fig. 2. Strategies used for the synthesis of MDMA using MDA as starting material. Method I-Ia: $\mathrm{O}\left(\mathrm{COCF}_{3}\right)_{2}, \mathrm{Pyr} \mathrm{CH}_{2} \mathrm{Cl}_{2} ; 0^{\circ} \mathrm{C}, 2 \mathrm{~h}$. $\mathrm{Ib}_{\mathrm{NaH}} \mathrm{NaH}, \mathrm{CH}_{3} \mathrm{I}, \mathrm{DMF} ; 20^{\circ} \mathrm{C}$, 10 h. Ic: $\mathrm{Cs}_{2} \mathrm{CO}_{3}, \mathrm{MeOH}, \mathrm{H}_{2} \mathrm{O} ; \Delta, 2 \mathrm{~h}$ (overall yield: $41.6 \%$ ). Method II-IIa: $\mathrm{ClCOOC}_{2} \mathrm{H}_{5}, \mathrm{NaOH}, \mathrm{H}_{2} \mathrm{O} ; 0{ }^{\circ} \mathrm{C}, 1.5 \mathrm{~h}$. IIb: LiALH $\mathrm{LHHF}_{4}, \mathrm{TH}_{1}, 13 \mathrm{~h}$ (overall yield: 51.7\%). Method III: $\mathrm{HCHO}, \mathrm{NaBH}_{3} \mathrm{CN}, \mathrm{MeOH}, \mathrm{AcOH} ; \mathrm{rt}, 3 \mathrm{~h}$ (overall yield: $33.3 \%$ ). Method IV—IVa: $\mathrm{HCOOC}_{2} \mathrm{H}_{5} ; \Delta, \mathrm{N}_{2}, 6 \mathrm{~h} . \mathrm{IVb}_{\mathrm{L}} \mathrm{LiAlH} 4, \mathrm{THF} ; \Delta, \mathrm{N}_{2}, 4 \mathrm{~h}$ (overall yield: $37.1 \%$ ). 
acid (5:5:0.1); chloroform/acetone/formic acid (8:2:0.1); chloroform/methanol/formic acid $(7: 3: 0.1)$. The spots were visualised under UV detection (254 and $366 \mathrm{~nm}$ ) and iodine vapour.

The purity of the final products ( $>98 \%$ purity) was verified using a high-performance liquid chromatography (HPLC) system equipped with UV detector. HPLC-UV chromatograms were obtained in a Jasco instrument (pumps model 880-PU and solvent mixing model 880-30, Tokyo, Japan), equipped with a Nucleosil RP-18 column ( $250 \mathrm{~mm} \times 4.6 \mathrm{~mm}, 5 \mu \mathrm{m}$, MachereyNagel, Düren, Germany), and UV detection at $280 \mathrm{~nm}$ (Jasco model 875-UV). pH 3 phosphate buffer/methanol (6:1) was used as the mobile phase, in isocratic flow rate of $1.2 \mathrm{~mL} \mathrm{~min}^{-1}$. The chromatographic data was processed in a Compaq computer, fitted with CSW 1.7 software (DataApex, Czech Republic).

\subsubsection{Synthesis of MDA (3,4-methylenedioxyamphetamine)}

MDA was synthesised by an adaptation of a previous described method (Fig. 1) [11]. Briefly, a Henry reaction between nitroethane and piperonal (3,4-methylenedioxybenzaldehyde) was performed through basic catalysis of ammonium acetate followed by water elimination. The resulting $\beta$-methyl- $\beta$-nitrostyrene derivative was then reduced to the corresponding phenethylamine (MDA) by lithium aluminium hydride. The obtained free base oil was used straightforward into the next syntheses.

$(R, S)$-3,4-Methylenedioxyamphetamine hydrochloride $(M D A) .{ }^{1} \mathrm{H}$ NMR $\delta: 1.10\left(3 \mathrm{H}, \mathrm{d}, \mathrm{CH}_{3}\right), 2.60(1 \mathrm{H}, \mathrm{dd}, J=13.4$; $\left.8.5, \mathrm{CH}_{2}\right), 2.89\left(1 \mathrm{H}, \mathrm{dd}, J=13.4 ; 5.2, \mathrm{CH}_{2}\right), 3.35(1 \mathrm{H}, \mathrm{m}, \mathrm{CH})$, $5.99\left(2 \mathrm{H}, \mathrm{s}, \mathrm{OCH}_{2} \mathrm{O}\right), 6.62(1 \mathrm{H}, \mathrm{dd}, J=7.8 ; 1.2, \mathrm{H}(6)), 6.74$ $(1 \mathrm{H}, \mathrm{d}, J=1.2, \mathrm{H}(2)), 6.78(1 \mathrm{H}, \mathrm{d}, J=7.9, \mathrm{H}(5)), 8.08(3 \mathrm{H}$, bs, $\left.\mathrm{NH}_{3}{ }^{+}\right) ;{ }^{13} \mathrm{C}$ NMR $\delta: 17.6 \mathrm{CH}_{3}, 39.7 \mathrm{CH}_{2}, 48.0 \mathrm{CH}, 100.8$ $\left(\mathrm{OCH}_{2} \mathrm{O}\right), 108.3,109.5 \mathrm{C}(2)$ and $\mathrm{C}(5), 122.4 \mathrm{C}(6), 130.4 \mathrm{C}(1)$, $146.0 \mathrm{C}(3), 147.4 \mathrm{C}(4)$; EI-MS $\mathrm{m} / \mathrm{z}(\%): 179\left(M^{\bullet+}, 3\right), 162$ (4), 136 (100), 105 (12), 82 (8), 77 (35), 65 (5), 58 (8); mp $186-188^{\circ} \mathrm{C}$.

\subsubsection{Synthesis of 3,4-methylenedioxymethamphetamine (MDMA, "ecstasy")}

2.2.4.1. Method I. (Ia) N-Trifluoroacetyl-3,4-methylenedioxyamphetamine: MDA as a free base $(3.55 \mathrm{~g}, 19.8 \mathrm{mmol})$ was dissolved in dry dichloromethane $(30 \mathrm{~mL})$, under nitrogen, with the following addition of pyridine $(2.3 \mathrm{~mL}, 28.5 \mathrm{mmol})$. The solution was ice-cooled and trifluoroacetic anhydride $(3.8 \mathrm{~mL}$, $27.3 \mathrm{mmol}$ ) was added dropwise to the reaction vessel. The mixture was allowed to reach room temperature and stirred for more $2 \mathrm{~h}$. The solution was washed with water $(30 \mathrm{~mL})$ and the organic layer dried $\left(\mathrm{MgSO}_{4}\right)$ and evaporated under reduced pressure. The obtained residue $(5.17 \mathrm{~g}, 18.8 \mathrm{mmol})$ was purified by column chromatography (silica gel; petroleum ether/diethyl ether $(7: 3))$.

(Ib) N-Trifluoroacetyl-3,4-methylenedioxymethamphetamine: $\quad N$-Trifluoroacetyl-3,4-methylenedioxyamphetamine $(5.17 \mathrm{~g}, 18.8 \mathrm{mmol})$ was dissolved in DMF $(25 \mathrm{~mL})$ and a $60 \%$ dispersion in mineral oil of sodium hydride $(0.80 \mathrm{~g}$, $33.3 \mathrm{mmol}$ ) was added to the solution. The reaction was stirred during $2 \mathrm{~h}$ at room temperature. Then methyl iodide $(1.3 \mathrm{~mL}$, $20.9 \mathrm{mmol}$ ) was added and the mixture was stirred for further
$8 \mathrm{~h}$. After this time the reaction medium was transferred to a vessel containing a $0.1 \mathrm{M}$ solution of acetic acid $(15 \mathrm{~mL})$. The product was extracted with dichloromethane $(3 \times 50 \mathrm{~mL})$ and the organic phase was dried $\left(\mathrm{MgSO}_{4}\right)$ and evaporated under reduced pressure. The product was subsequently purified by $\mathrm{CC}$ to remove the mineral oil (silica gel; dichloromethane/ethyl acetate in different proportions) (3.34 g, $11.5 \mathrm{mmol})$.

(Ic) 3,4-Methylenedioxymethamphetamine (MDMA): To a solution of $N$-trifluoroacetyl-3,4-methylenedioxymethamphetamine $(3.34 \mathrm{~g}, 11.5 \mathrm{mmol})$ in a mixture of methanol/water $(1: 1)(30 \mathrm{~mL})$ cesium carbonate $(8.48 \mathrm{~g}$, $26.0 \mathrm{mmol}$ ) was added and the resulting mixture was refluxed for $1.5 \mathrm{~h}$. After partial evaporation of the solvent and sequential addition of water $(70 \mathrm{~mL})$, the compound was extracted with ethyl acetate $(2 \times 100 \mathrm{~mL})$. The solvent was dried over magnesium sulphate and evaporated. The residue was recrystallised with methanol acidified with $\mathrm{HCl}$ and the MDMA hydrochloride was obtained as white solid product after addition of diethyl ether ( $1.89 \mathrm{~g}$, overall yield: $41.6 \%)$.

$(R, S)-3,4-M e t h y l e n e d i o x y m e t h a m p h e t a m i n e$ hydrochloride (MDMA). ${ }^{1} \mathrm{H}$ NMR $\delta: 1.08\left(3 \mathrm{H}, \mathrm{d}, \mathrm{CH}_{3}\right), 2.54\left(3 \mathrm{H}, \mathrm{s}, \mathrm{NCH}_{3}\right)$, $2.56\left(1 \mathrm{H}, \mathrm{dd}, J=13.4 ; 8.7, \mathrm{CH}_{2}\right), 3.04(1 \mathrm{H}, \mathrm{dd}, J=13.4 ; 4.5$, $\left.\mathrm{CH}_{2}\right), 3.33(1 \mathrm{H}, \mathrm{m}, \mathrm{CH}), 5.99\left(2 \mathrm{H}, \mathrm{s}, \mathrm{OCH}_{2} \mathrm{O}\right), 6.70(1 \mathrm{H}, \mathrm{dd}$, $J=8.0 ; 1.6, \mathrm{H}(6)), 6.86(1 \mathrm{H}, \mathrm{d}, J=1.6, \mathrm{H}(2)), 6.87(1 \mathrm{H}, \mathrm{d}, J=7.9$, $\mathrm{H}(5)), 8.78\left(2 \mathrm{H}\right.$, bs, $\left.\mathrm{NH}_{2}{ }^{+}\right) ;{ }^{13} \mathrm{C} \mathrm{NMR} \delta: 14.8 \mathrm{CH}_{3}, 29.4 \mathrm{NCH}_{3}$, $37.7 \mathrm{CH}_{2}, 55.1 \mathrm{CH}, 100.7 \mathrm{OCH}_{2} \mathrm{O}, 108.1,109.3 \mathrm{C}(2)$ and $\mathrm{C}(5)$, 122.2 C(6), 130.6 C(1), 146.3 C(3), 147.7 C(4); EI-MS m/z (\%): $193\left(M^{\bullet+}, 9\right), 178$ (12), 163 (10), 135 (100), 105 (25), 89 (28), 83 (16), 77 (98); mp $148-150^{\circ} \mathrm{C}$.

\subsubsection{Method II. (IIa) N-Carbethoxy-3,4-methylenedioxy-} amphetamine: MDA $(0.81 \mathrm{~g}, 4.5 \mathrm{mmol})$ as a free base was dissolved in water $(30 \mathrm{~mL})$ at $0{ }^{\circ} \mathrm{C}$. A solution of $\mathrm{NaOH}(0.3 \mathrm{~g})$ in water $(2.5 \mathrm{~mL})$ was then added to the reaction with following addition of ethyl chloroformate $(0.5 \mathrm{~mL}, 5.3 \mathrm{mmol})$. The suspension was stirred at $0{ }^{\circ} \mathrm{C}$ for $2 \mathrm{~h}$ and the reaction was then stopped by extraction with dichloromethane $(3 \times 100 \mathrm{~mL})$. The organic layer was dried $\left(\mathrm{Na}_{2} \mathrm{SO}_{4}\right)$ and the solvent was evaporated to obtain the corresponding carbamate $(0.95 \mathrm{~g}, 3.8 \mathrm{mmol})$.

(IIb) 3,4-Methylenedioxymethamphetamine (MDMA): The carbamate $(0.95 \mathrm{~g}, 3.8 \mathrm{mmol})$ was dissolved in THF $(15 \mathrm{~mL})$ and this solution was slowly added to lithium aluminium hydride $(12 \mathrm{mmol})$ suspended in THF $(25 \mathrm{~mL})$, under $\mathrm{N}_{2}$. The reaction was stirred, heated under reflux for $10 \mathrm{~h}$ and then allowed to cool to room temperature. The excess of $\mathrm{LiAlH}_{4}$ was decomposed and the reaction quenched by smooth addition of cold water/ice with vigorous stirring. The inorganic residue was removed by vacuum filtration; the solvent was dried over anhydrous magnesium sulphate, evaporated, the residue diluted with diethyl ether and extracted with aqueous $\mathrm{HCl}(3 \times 100 \mathrm{~mL}$ of a $2 \mathrm{M}$ solution). The acidic extract was alkalinised with a $\mathrm{NaOH}$ solution and extracted with diethyl ether $(3 \times 100 \mathrm{~mL})$. The organic layer was dried over anhydrous magnesium sulphate, filtered and concentrated to yield a light coloured oil turned into a white solid of MDMA hydrochloride by the addition of ethereal $\mathrm{HCl}(0.53 \mathrm{~g}$, overall yield: $51.7 \%$ ). 
2.2.4.3. Method III. MDA (2.00 g, $11.7 \mathrm{mmol})$ as a free base was dissolved in methanol $(50 \mathrm{~mL})$ acidified with acetic acid until $\mathrm{pH}$ 5. Formaldehyde $(1 \mathrm{~mL}$ of a $37 \%$ solution in water, $12.3 \mathrm{mmol})$ and sodium cyanoborohydride $(0.98 \mathrm{~g}, 15.6 \mathrm{mmol})$ were then slowly added to the solution. The reaction was stirred at room temperature during $3 \mathrm{~h}$. After that the solvent was evaporated and the resulting yellowish oil was dissolved in methanol, the solution was acidified with $\mathrm{HCl}$ and diethyl ether was added until insolubilisation. A white solid identified as MDMA hydrochloride was obtained ( $0.89 \mathrm{~g}$, yield: $33.3 \%$ ).

\subsubsection{Method IV. (IVa) N-Formyl-3,4-methylenedioxyam-} phetamine: MDA $(1.59 \mathrm{~g}, 8.9 \mathrm{mmol})$ as a free base was suspended in ethyl formate $(50 \mathrm{~mL})$ and the ensuing mixture was heated to reflux providing a homogeneous solution. After $6 \mathrm{~h}$, the excess of ethyl formate was removed under reduced pressure, and the resulting yellow solid of the formamide $(1.59 \mathrm{~g}$, $7.7 \mathrm{mmol}$ ) was identified and used without further purification in the next reaction.

(IVb) 3,4-Methylenedioxymethamphetamine (MDMA): A solution of $\mathrm{N}$-formyl-3,4-methylenedioxyamphetamine (1.59g, $7.7 \mathrm{mmol}$ ) in anhydrous tetrahydrofuran $(25 \mathrm{~mL})$ was added dropwise to a stirred solution of lithium aluminium hydride $(15 \mathrm{mmol})$ in anhydrous tetrahydrofuran $(35 \mathrm{~mL})$, while cooling with ice-water in an inert environment $\left(\mathrm{N}_{2}\right)$. The mixture was allowed to warm up to room temperature and then refluxed for $4 \mathrm{~h}$ more. After cooling and decomposing the hydride excess by the cautious addition of water, the precipitated inorganic salts were eliminated by filtration. The combined organic solutions were dried over sodium sulphate and concentrated to yield a yellow oil that was dissolved in methanol and acidified with an ethereal solution of $\mathrm{HCl}$ to obtain a almost white solid identified as MDMA (0.76 g, overall yield: $37.1 \%$ ).

\subsection{Electrochemical measurements}

For the electrochemical measurements, $10 \mathrm{mM}$ stock solutions of MDMA, MDA, 3,4-methylenedioxy- $\beta$-methyl$\beta$-nitrosyrene and piperonal were made by dissolving an appropriate amount of compound in water or ethanol, depending on their solubility. The voltammetric working solutions were prepared, in the electrochemical cell, by diluting $100 \mu \mathrm{L}$ of the stock solution in $10 \mathrm{~mL}$ of supporting electrolyte, in order to get a final concentration of $0.1 \mathrm{mM}$.

The $\mathrm{pH} 7.3$ supporting electrolyte used in the voltammetric determinations was prepared by diluting $6.2 \mathrm{~mL}$ of $0.2 \mathrm{M}$ dipotassium hydrogen phosphate and $43.8 \mathrm{~mL}$ of $0.2 \mathrm{M}$ potassium dihydrogen phosphate to $100 \mathrm{~mL}$.

Voltammetric studies were performed using an Autolab PGSTAT 12 potentiostat/galvanostat (Eco-Chemie, Netherlands) and a one-compartment glass electrochemical cell. Voltammetric curves were recorded, at room temperature and without oxygen purging, using a three-electrode system. A glassy carbon working electrode (GCE) $(d=2 \mathrm{~mm})$, a platinum wire counter electrode and an $\mathrm{Ag} / \mathrm{AgCl}$ saturated $\mathrm{KCl}$ reference electrode were used. The working electrode was polished manually with aqueous slurry of alumina powder (BDH) on a microcloth pad and rinsed with water before use. A Crison $\mathrm{pH}-$ meter with glass electrode was used for the $\mathrm{pH}$ measurements (Crison, Spain).

\subsection{Quantum mechanical calculations}

The quantum mechanical calculations - geometry optimisation and calculation of the harmonic vibrational frequencies - were performed using the GAUSSIAN 98W program [22], within the Density Functional Theory (DFT) approach in order to properly represent the electron correlation effects. The B3LYP hybrid method, which includes a mixture of HF and DFT exchange terms and the gradient-corrected correlation functional of Lee et al. $[23,24]$ as proposed and parameterised by Becke $[25,26]$, was used, along with the double-zeta split valence basis set 6-31G* [27].

Molecular geometries were fully optimised by the Berny algorithm, using redundant internal coordinates [28]: the bond lengths to within $c a .0 .1 \mathrm{pm}$ and the bond angles to within $c a$. $0.1^{\circ}$. The final root-mean-square (rms) gradients were always less than $3 \times 10^{-4}$ hartree bohr $^{-1}$ or hartree radian ${ }^{-1}$. No geometrical constraints were imposed on the molecules under study.

Frequency calculations were run, at the B3LYP/6-31G* level, for all the energy minima obtained for the molecules under study. In view of accounting for the anharmonicity, wavenumbers above $400 \mathrm{~cm}^{-1}$ were scaled using a factor of 0.9614 according to Scott and Radom [29], before comparing them with the experimental data.

\subsection{Raman spectroscopy}

The Raman spectra were obtained at room temperature, on a triple monochromator Jobin-Yvon T64000 Raman system $(0.640 \mathrm{~m}, f / 7.5)$, with holographic gratings of 1800 grooves $\mathrm{mm}^{-1}$. The detection system was a non-intensified CCD (Charge Coupled Device). The entrance slit was set to $200 \mu \mathrm{m}$ and the slit between the premonochromator and the spectrograph was opened to $14.0 \mathrm{~mm}$. The $514.5 \mathrm{~nm}$ line of an $\mathrm{Ar}^{+}$laser (Coherent, model Innova 300) was used as the excitation radiation, providing between 10 and $50 \mathrm{~mW}$ at the sample position. Samples were sealed in Kimax glass capillary tubes of $0.8 \mathrm{~mm}$ inner diameter. Under the above-mentioned conditions, the error in wavenumbers was estimated to be within $1 \mathrm{~cm}^{-1}$.

\section{Results and discussion}

\subsection{Chemistry}

The synthesis of MDMA from MDA is outlined in Fig. 2 and the related structural elucidation data is presented in Section 2.

In general, amines can be $\mathrm{N}$-alkylated through several pathways by the use of a key property of the nitrogen atom, its nucleophilicity. The alkylation methods are usually indirect, since the reaction of amines with haloalkanes is usually slow and not clean. Indeed, the $N$-methylation of a primary amine frequently results in a mixture of the secondary and the tertiary amine. Due to this difficulty four indirect alkylation processes 
were designed, experimented and compared (methods I-IV), aiming at an improvement of the overall yield and of the purity of the final product.

Briefly, in the first procedure (method I), a simple modification of the direct method was chosen, in which a trifluoroacetyl group is used to generate an acetamide derivative $\left(N-\mathrm{COCF}_{3}\right.$, $\mathrm{N}$-TFA). This group is readily attached to the nitrogen atom by reaction of the primary amine with trifluoroacetic anhydride $\left(\left(\mathrm{CF}_{3} \mathrm{CO}\right)_{2} \mathrm{O}\right)$ in the presence of a base (triethylamine or pyridine), at low temperature [30,31]. Then, after $N$-alkylation with methyl iodide, the resulting $N$-methyltrifluoroacetamide is easily cleaved ( $N$-deacylation) in basic conditions [30].

On the other hand, method II is based on the synthesis of a carbamate intermediate (NCOOR), a classic example of protecting group for amines. The most common one is the ethylcarbamate $\left(\mathrm{NCOOCH}_{2} \mathrm{CH}_{3}\right)$, a group obtained by reaction of the amine with ethyl chloroformate in the presence of a base (Method II). This group is usually reduced by most of hydrides, like $\mathrm{LiAlH}_{4}$, giving the corresponding $N$-methylamines [32].

Method III seemed an attractive approach to MDMA synthesis from MDA since it corresponds to a one-pot reaction in which MDA is treated with an aldehyde (formaldehyde) in the presence of sodium cyanoborohydride as a catalyst. In these synthetic conditions the amine group undergoes a reductive methylation $[31,33]$.

Method IV is based on a $\mathrm{N}$-formylation of the primary amine (MDA) with ethyl formate $\left(\mathrm{HCO}_{2} \mathrm{Et}\right)$ providing the corresponding formamide intermediate (IVa) which after reduction

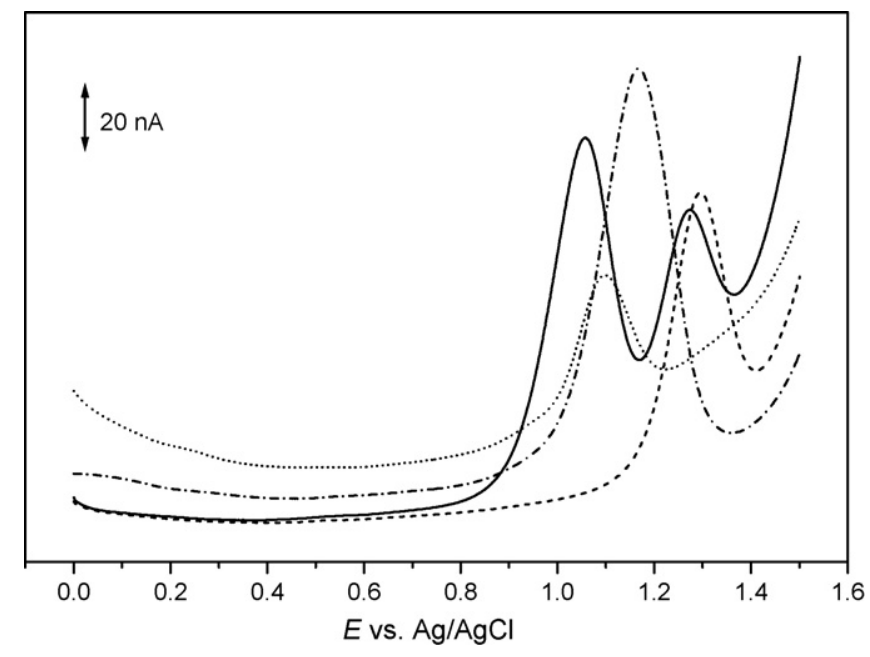

Fig. 3. Differential pulse voltammograms for $0.1 \mathrm{mM}$ solutions of (-) MDMA, (..) MDA, (---) 3,4-methylenedioxybenzaldehyde and (- - .) 3,4methylenedioxy- $\beta$-methyl- $\beta$-nitrostyrene, in physiological $\mathrm{pH} 7.3$ supporting electrolyte. Scan rate: $5 \mathrm{mV} \mathrm{s}^{-1}$.

with lithium aluminium hydride gave the $N$-methyl compound (MDMA) $[34,35]$ in relative good yields.

It is worth mentioning that the synthesised amines were isolated and used in the analytical assays after obtention of their hydrochloride salts. However, prior to the $N$-methylation, the regeneration of the base from its salt form must be conducted after alkalinisation with ammonia. This step is important since
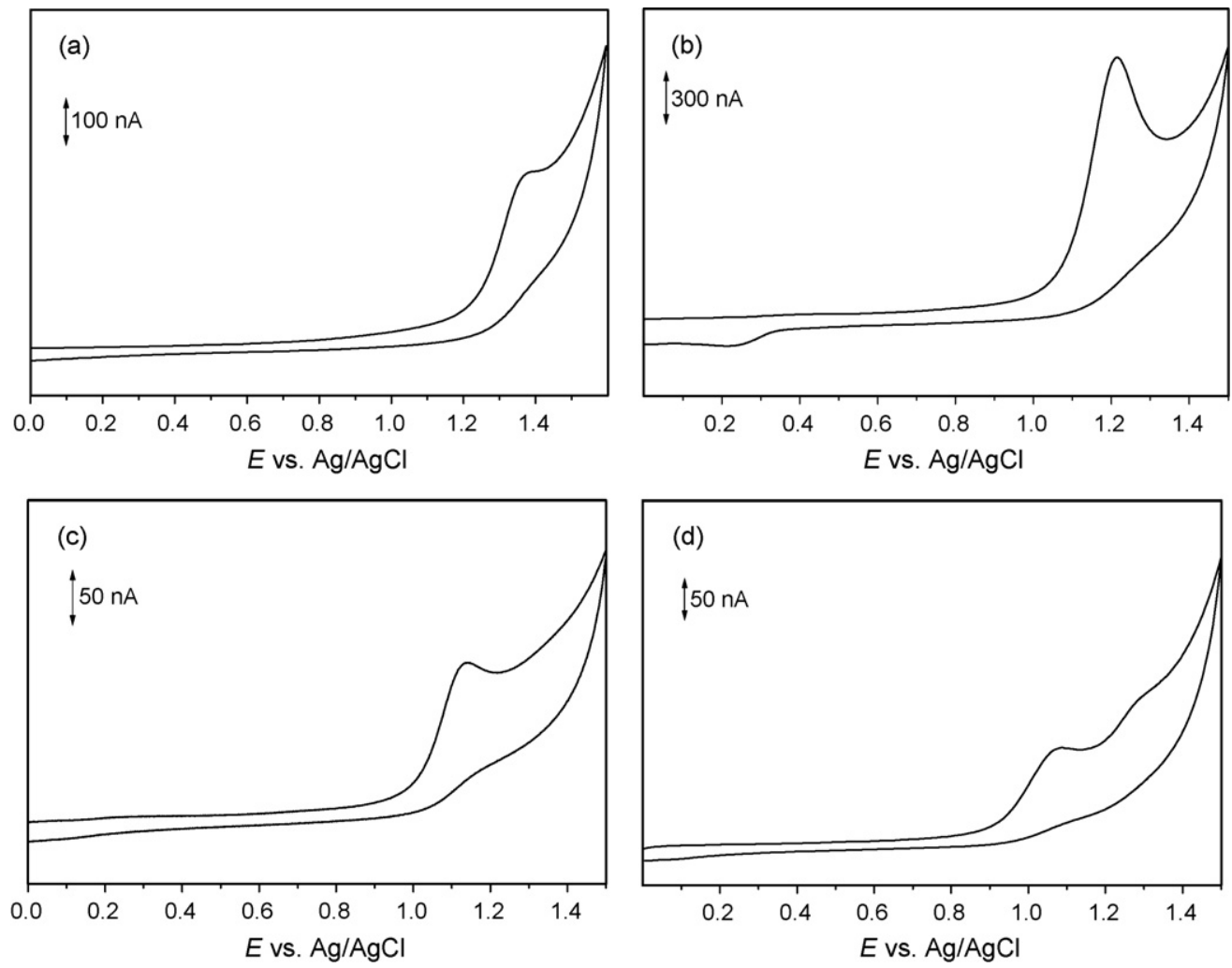

Fig. 4. Cyclic voltammograms for $0.1 \mathrm{mM}$ solutions of (a) 3,4-methylenedioxybenzaldehyde, (b) 3,4-methylenedioxy- $\beta$-methyl- $\beta$-nitrostyrene, (c) MDA and (d) MDMA, in physiological $\mathrm{pH} 7.3$ supporting electrolyte. Scan rate: $50 \mathrm{mV} \mathrm{s}^{-1}$. 
the lone pair of electrons on the nitrogen was unavailable to the usual reactions involving amines (alkylation and/or oxidation).

\subsection{Electrochemical oxidation}

To increase the understanding of the redox profile of the drugs, important for the advance of the knowledge of molecular toxicological mechanisms and the development of new analytical assays, the electrochemical behaviour of MDMA, MDA and their synthetic precursors 3,4-methylenedioxybenzaldehyde (piperonal) and 3,4-methylenedioxy- $\beta$-methyl- $\beta$-nitrostyrene was studied at physiological $\mathrm{pH}$, at a glassy carbon working electrode (GCE) using differential pulse and cyclic voltammetry.

For MDMA, two well-defined anodic peaks can be observed at physiological $\mathrm{pH}$ using differential pulse voltammetry (Fig. 3). The first oxidation peak, $E_{\mathrm{p}}=+1.05 \mathrm{~V}$, is probably due to the removal of one electron from the aromatic nucleus. The second wave, $E_{\mathrm{p}}=+1.26 \mathrm{~V}$, corresponds to the oxidation of the secondary amine present in the MDMA molecule. Cyclic voltammograms were also recorded at different sweep rates. Two well-defined anodic peaks were observed for MDMA at physiological pH (Fig. 4). The fact that no peaks were observed in the reversed scan suggests that the oxidation processes are irreversible. These peaks correspond to the above-described waves observed by differential pulse voltammetry.

The electrochemical study of MDMA synthetic impurities, MDA, 3,4-methylenedioxybenzaldehyde (piperonal) and 3,4methylenedioxy- $\beta$-methyl- $\beta$-nitrostyrene enabled to get insight the established mechanistic hypothesis that the groups involved in the oxidation of MDMA are the aromatic electrophore and the secondary amine. For these compounds, only a single and well-defined anodic oxidation wave is noticed at physiological $\mathrm{pH}$ that can be attributed to the removal of one electron from the aromatic nucleus. Cyclic voltammetric measurements performed showed the irreversible nature of the oxidation waves for these compounds (Fig. 4). The differences observed for these compounds in terms of peak potential and peak current may be due to the nature and electrophilic properties of the substituent in the aromatic ring.

The only structural difference between MDMA and MDA lies in the amine group, MDMA has a secondary and MDA a primary amine group. Thus, the second wave observed for MDMA could only be related with the oxidation of the secondary amine group. The appearance of a peak at this $E_{\mathrm{p}}$ value resulting from the oxidation of aliphatic secondary amines has also been described in the literature for other aliphatic amines [36,37]. Previous published works using compounds structurally related with MDMA also showed the occurrence of an anodic wave that has been undoubtedly attributed to the oxidation of the secondary amine [37-39].

The first peak observed for MDMA, $E_{\mathrm{p}}=+1.05 \mathrm{~V}$, ascribed to the oxidation of the aromatic electrophore also occurs for MDA, $E_{\mathrm{p}}=+1.06 \mathrm{~V}$. The inexistence of other groups in the molecule capable of being oxidised could itself justify this attribution. In addition, it could be found in literature some studies involving compounds possessing similar functionalities that present a wave at similar potentials to that established for MDMA and
(A)
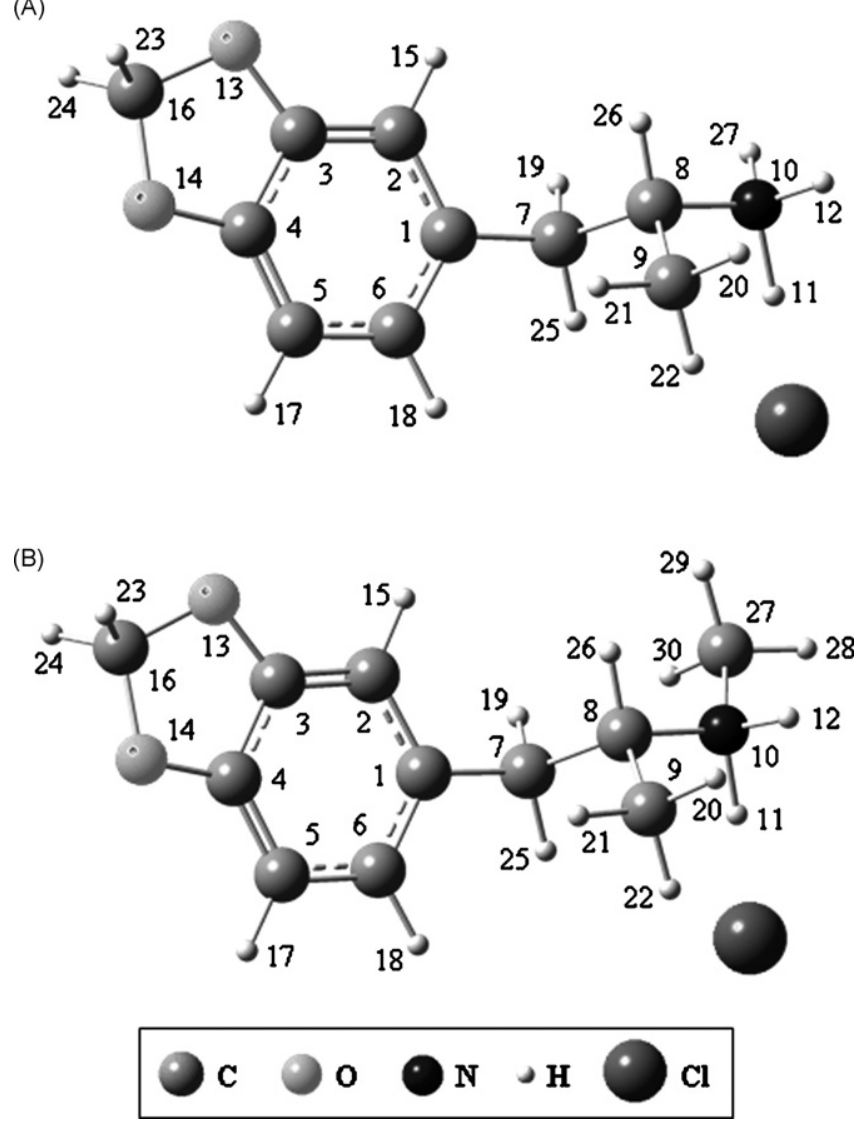

Fig. 5. Schematic representation of the most stable calculated (B3LYP/6-31G*) conformers for the hydrochloride salts of 3,4-methylenedioxyamphetamine (MDA) (A) and 3,4-methylenedioxymethamphetamine (MDMA) (B). (The atom numbering is included.)

MDA and that were also directly related to the oxidation of the aromatic ring [40,41].

Besides the importance of redox data for toxicological studies, in which metabolism is an important pathway, its importance is noteworthy for analytical forensic assays in which an electrochemical detector is often used due to its sensitivity and selectivity (e.g. HPLC).

\subsection{Conformational analysis}

The geometry optimisation carried out for both MDA and MDMA ("ecstasy") hydrochlorides allowed to obtain their low energy conformers represented in Fig. 5. The corresponding theoretical vibrational spectra were yielded by the harmonic frequency calculations (which also confirmed these geometries as real minima in the potential energy surface). In MDA and MDMA the unsaturated aliphatic $\left(\mathrm{C}_{7} \mathrm{C}_{8} \mathrm{~N}_{10}\right)$ side chain was found to be almost perpendicular relative to the coplanar aromatic and methylenedioxy rings $-\left(\mathrm{C}_{2} \mathrm{C}_{1} \mathrm{C}_{7} \mathrm{C}_{8}\right)$ equal to $73.9^{\circ}$ for "ecstasy" and $75.4^{\circ}$ for MDA (Table 1) - thus minimising steric repulsions between the $\mathrm{C}_{8}$-methyl and aromatic hydrogens $\left(\mathrm{H}_{15}\right.$ or $\left.\mathrm{H}_{18}\right)$.

$N$-Methylation of MDA, yielding its $N$-methyl analogue "ecstasy" (MDMA), occurs in a trans position relative to the 
Table 1

Relevant calculated (B3LYP/6-31G*) geometric parameters for the most stable conformers of MDA and MDMA

\begin{tabular}{|c|c|c|}
\hline$\mu(\mathrm{D})^{\mathrm{a}}$ & $\begin{array}{l}\text { MDA } \\
(8.4)\end{array}$ & $\begin{array}{l}\text { MDM } \\
(8.8)\end{array}$ \\
\hline \multicolumn{3}{|l|}{ Bond lengths (pm) } \\
\hline $\mathrm{C}_{1}-\mathrm{C}_{2} \mathrm{~b}$ & 141.4 & 141.4 \\
\hline $\mathrm{C}_{3}-\mathrm{C}_{4}$ & 139.4 & 139.4 \\
\hline $\mathrm{C}_{5}-\mathrm{C}_{6}$ & 140.8 & 140.8 \\
\hline $\mathrm{C}_{1}-\mathrm{C}_{7}$ & 151.4 & 151.5 \\
\hline $\mathrm{C}_{7}-\mathrm{C}_{8}$ & 154.4 & 154.4 \\
\hline $\mathrm{C}_{8}-\mathrm{C}_{9}$ & 152.7 & 152.9 \\
\hline $\mathrm{C}_{3}-\mathrm{O}_{13}$ & 137.4 & 137.4 \\
\hline $\mathrm{C}_{4}-\mathrm{O}_{14}$ & 137.4 & 137.5 \\
\hline $\mathrm{C}_{16}-\mathrm{O}_{13}$ & 143.3 & 143.3 \\
\hline $\mathrm{C}_{8}-\mathrm{N}_{10}$ & 150.3 & 150.9 \\
\hline $\mathrm{C}_{27}-\mathrm{N}_{10}$ & - & 148.2 \\
\hline $\mathrm{C}_{2}-\mathrm{H}_{15}$ & 108.6 & 108.6 \\
\hline $\mathrm{C}_{16}-\mathrm{H}_{23}$ & 109.4 & 109.4 \\
\hline $\mathrm{C}_{7}-\mathrm{H}_{19}$ & 110.0 & 109.7 \\
\hline $\mathrm{C}_{8}-\mathrm{H}_{26}$ & 109.8 & 109.9 \\
\hline $\mathrm{C}_{9}-\mathrm{H}_{20}$ & 109.7 & 109.7 \\
\hline $\mathrm{C}_{9}-\mathrm{H}_{21}$ & 109.2 & 109.2 \\
\hline $\mathrm{N}_{10}-\mathrm{H}_{11}$ & 122.0 & 116.3 \\
\hline $\mathrm{N}_{10}-\mathrm{H}_{12}$ & 102.2 & 102.2 \\
\hline $\mathrm{C}_{27}-\mathrm{H}_{28}$ & - & 109.2 \\
\hline $\mathrm{C}_{27}-\mathrm{H}_{29}$ & - & 109.4 \\
\hline \multicolumn{3}{|l|}{ Bond angles $\left({ }^{\circ}\right)$} \\
\hline $\mathrm{C}_{6}-\mathrm{C}_{1}-\mathrm{C}_{2}$ & 119.7 & 119.7 \\
\hline $\mathrm{C}_{6}-\mathrm{C}_{1}-\mathrm{C}_{7}$ & 120.5 & 120.6 \\
\hline $\mathrm{C}_{1}-\mathrm{C}_{7}-\mathrm{C}_{8}$ & 113.2 & 112.8 \\
\hline $\mathrm{C}_{7}-\mathrm{C}_{8}-\mathrm{C}_{9}$ & 113.9 & 113.2 \\
\hline $\mathrm{O}_{13}-\mathrm{C}_{16}-\mathrm{O}_{14}$ & 108.1 & 108.0 \\
\hline $\mathrm{C}_{4}-\mathrm{C}_{3}-\mathrm{O}_{13}$ & 109.7 & 109.7 \\
\hline $\mathrm{C}_{3}-\mathrm{O}_{13}-\mathrm{C}_{16}$ & 105.7 & 105.6 \\
\hline $\mathrm{C}_{7}-\mathrm{C}_{8}-\mathrm{N}_{10}$ & 107.6 & 109.7 \\
\hline $\mathrm{C}_{8}-\mathrm{N}_{10}-\mathrm{C}_{27}$ & - & 117.3 \\
\hline $\mathrm{C}_{1}-\mathrm{C}_{7}-\mathrm{H}_{19}$ & 109.4 & 108.9 \\
\hline $\mathrm{C}_{7}-\mathrm{C}_{8}-\mathrm{H}_{26}$ & 109.3 & 109.5 \\
\hline $\mathrm{C}_{8}-\mathrm{C}_{9}-\mathrm{H}_{20}$ & 111.1 & 111.2 \\
\hline $\mathrm{O}_{13}-\mathrm{C}_{16}-\mathrm{H}_{23}$ & 109.4 & 109.4 \\
\hline $\mathrm{N}_{10}-\mathrm{C}_{27}-\mathrm{H}_{28}$ & - & 108.3 \\
\hline $\mathrm{N}_{10}-\mathrm{C}_{27}-\mathrm{H}_{29}$ & - & 110.8 \\
\hline $\mathrm{H}_{20}-\mathrm{C}_{9}-\mathrm{H}_{21}$ & 107.9 & 107.9 \\
\hline $\mathrm{H}_{23}-\mathrm{C}_{16}-\mathrm{H}_{24}$ & 110.9 & 111.0 \\
\hline \multicolumn{3}{|l|}{ Dihedral angles $\left({ }^{\circ}\right)$} \\
\hline $\mathrm{C}_{1}-\mathrm{C}_{2}-\mathrm{C}_{3}-\mathrm{C}_{4}$ & 0.0 & -0.1 \\
\hline $\mathrm{C}_{3}-\mathrm{C}_{2}-\mathrm{C}_{1}-\mathrm{C}_{7}$ & -179.4 & -179.8 \\
\hline $\mathrm{C}_{2}-\mathrm{C}_{1}-\mathrm{C}_{7}-\mathrm{C}_{8}$ & 75.4 & 73.9 \\
\hline $\mathrm{C}_{1}-\mathrm{C}_{7}-\mathrm{C}_{8}-\mathrm{C}_{9}$ & 64.6 & 62.6 \\
\hline $\mathrm{C}_{1}-\mathrm{C}_{7}-\mathrm{C}_{8}-\mathrm{N}_{10}$ & -175.6 & -177.6 \\
\hline $\mathrm{C}_{7}-\mathrm{C}_{8}-\mathrm{N}_{10}-\mathrm{C}_{27}$ & - & 65.2 \\
\hline $\mathrm{C}_{7}-\mathrm{C}_{8}-\mathrm{N}_{10}-\mathrm{H}_{11}$ & -61.2 & -57.0 \\
\hline $\mathrm{C}_{7}-\mathrm{C}_{8}-\mathrm{N}_{10}-\mathrm{H}_{12}$ & 179.5 & -170.7 \\
\hline $\mathrm{C}_{2}-\mathrm{C}_{3}-\mathrm{O}_{13}-\mathrm{C}_{16}$ & 174.2 & 173.6 \\
\hline $\mathrm{C}_{3}-\mathrm{O}_{13}-\mathrm{C}_{16}-\mathrm{O}_{14}$ & 10.6 & 11.6 \\
\hline $\mathrm{C}_{3}-\mathrm{O}_{13}-\mathrm{C}_{16}-\mathrm{H}_{23}$ & 129.6 & 130.7 \\
\hline $\mathrm{C}_{6}-\mathrm{C}_{1}-\mathrm{C}_{2}-\mathrm{H}_{15}$ & -179.1 & -179.1 \\
\hline $\mathrm{C}_{6}-\mathrm{C}_{1}-\mathrm{C}_{7}-\mathrm{H}_{19}$ & 134.9 & 132.3 \\
\hline $\mathrm{C}_{1}-\mathrm{C}_{7}-\mathrm{C}_{8}-\mathrm{H}_{26}$ & -58.7 & -60.5 \\
\hline $\mathrm{C}_{7}-\mathrm{C}_{8}-\mathrm{C}_{9}-\mathrm{H}_{20}$ & -177.9 & -177.3 \\
\hline $\mathrm{C}_{8}-\mathrm{N}_{10}-\mathrm{C}_{27}-\mathrm{H}_{28}$ & - & 171.3 \\
\hline
\end{tabular}

a $\mathrm{D}=1 / 3 \times 10^{-2} \mathrm{Cm}$.

b Atoms are numbered according to Fig. 5 . methyl group in $\mathrm{C}_{8}\left(\left(\mathrm{C}_{9} \mathrm{C}_{8} \mathrm{~N}_{10} \mathrm{C}_{27}\right)=-171.5^{\circ}\right.$, Fig. 5), in order to avoid repulsion effects between the two adjacent $\mathrm{CH}_{3}$ groups. Moreover, inclusion of the methyl group in the terminal amino moiety of the molecule is associated to a slight decrease of the $\left(\mathrm{C}_{1} \mathrm{C}_{7} \mathrm{C}_{8} \mathrm{C}_{9}\right)$ dihedral angle - from $64.6^{\circ}$ in MDA to $62.6^{\circ}$ in "ecstasy" - coupled to an increase for $\left(\mathrm{C}_{1} \mathrm{C}_{7} \mathrm{C}_{8} \mathrm{~N}_{10}\right)$ from $-175.6^{\circ}$ in MDA to $-177.6^{\circ}$ in "ecstasy" (Table 1). $\mathrm{N}$-Methylation also leads to a slight variation of the relative orientation of the $\mathrm{C}_{8}-\mathrm{C}_{9}$ bond relative to the plane of the rings $-\left(\mathrm{C}_{9} \mathrm{C}_{8} \mathrm{C}_{1} \mathrm{C}_{6}\right)=-26.4^{\circ}$ in MDA to $-29.9^{\circ}$ in MDMA - as well as to a reorientation of the amino group $-\left(\mathrm{C}_{7} \mathrm{C}_{8} \mathrm{~N}_{10} \mathrm{H}_{11}\right)$ and $\left(\mathrm{C}_{7} \mathrm{C}_{8} \mathrm{~N}_{10} \mathrm{H}_{12}\right)$ equal to $-61.2^{\circ}$ and $179.5^{\circ}$ in MDA versus $-57.0^{\circ}$ and $-170.7^{\circ}$ in "ecstasy" (Table 1).

\subsection{Raman spectroscopy}

The Raman spectra of MDA and MDMA are represented in Fig. 6 (from 100 to $1750 \mathrm{~cm}^{-1}$ ), along with the spectra of their synthetic precursors 3,4-methylene-dioxybenzaldehyde (piperonal) and 3,4-methylenedioxy- $\beta$-methyl- $\beta$-nitrostyrene. The corresponding vibrational wavenumbers were assigned in the light of the theoretical results presently carried out (Table 2) and the spectroscopic data previously reported for $\beta$-methyl- $\beta$-nitrostyrene derivatives [42-45] and similar compounds [46-52].

As previously verified [42], Raman spectroscopy proved to be quite adequate for a rapid and reliable characterisation of this type of system. In fact, the spectral patterns obtained in this work allow an unequivocal identification of the amphetamine MDA and the corresponding $N$-methyl derivative MDMA ("ecstasy") (Figs. 6 and 7). The former displays typical Raman bands at $836 / 861 \mathrm{~cm}^{-1}\left(\mathrm{CH}_{2}\right.$ in-plane deformation, $\delta\left(\mathrm{CH}_{2}\right) / \mathrm{CH}_{2}$ wagging, $\left.\omega\left(\mathrm{CH}_{2}\right)\right), 985-965 \mathrm{~cm}^{-1}\left(\mathrm{NH}_{3}\right.$ rocking, $\left.\mathrm{r}\left(\mathrm{NH}_{3}\right)\right), 1024 \mathrm{~cm}^{-1}$ (OCO ring deformation, $\delta(\mathrm{OCO})$ ), $1310 / 1319 \mathrm{~cm}^{-1}\left(\mathrm{NH}_{3}\right.$ in-plane deformation, $\left.\delta\left(\mathrm{NH}_{3}\right)\right)$, and $1355 \mathrm{~cm}^{-1}\left(\mathrm{r}\left(\mathrm{NH}_{3}\right)\right)$. MDMA, in turn, presents characteristic signals at $381-479 \mathrm{~cm}^{-1}$ (skeletal CCC, COC and CCN outof-plane deformations, $\Gamma(\mathrm{CCC} / \mathrm{COC}, \mathrm{CCN})), 855 \mathrm{~cm}^{-1}\left(\mathrm{NH}_{2}\right.$ rocking, $\mathrm{r}\left(\mathrm{NH}_{2}\right)$ ), $888 / 1040 / 1081 \mathrm{~cm}^{-1}$ (rocking of the $\mathrm{N}$ methyl group, $\left.\mathrm{r}\left(\mathrm{CH}_{3}\right)\right), 1199 \mathrm{~cm}^{-1}\left(\mathrm{NH}_{2}\right.$ twisting, $\left.\mathrm{t}\left(\mathrm{NH}_{2}\right)\right)$, and $1443 \mathrm{~cm}^{-1}\left(\mathrm{NH}_{2}\right.$ scissoring, $\left.\operatorname{sciss}\left(\mathrm{NH}_{2}\right)\right)$ (Table 2$)$.

The $\mathrm{NH}_{3}$ stretching (for MDA) is calculated at $3405 \mathrm{~cm}^{-1}$, while $v\left(\mathrm{NH}_{2}\right)$ (for "ecstasy") is calculated at $3339 \mathrm{~cm}^{-1}$. Since no significative intramolecular hydrogen-type interactions may occur in these molecules, the $\mathrm{NH}_{2} / \mathrm{NH}_{3}$ stretching vibrations can only be affected by interaction with the chloride counterion, which may explain why they are not detected in the experimental Raman spectra (added to the typical low intensity of these modes in Raman). Apart from the amino group stretching modes, a quite good agreement was found between the experimental and calculated frequencies for both MDA and MDMA (Fig. 8).

Raman spectroscopy was described to be a valuable technique for a complete characterisation of drugs of abuse, either in seizure or biological samples. In that way it was applied to easily identify MDA and MDMA, as well as to differentiate them from their synthetic precursors piperonal and 3,4- 
(A)

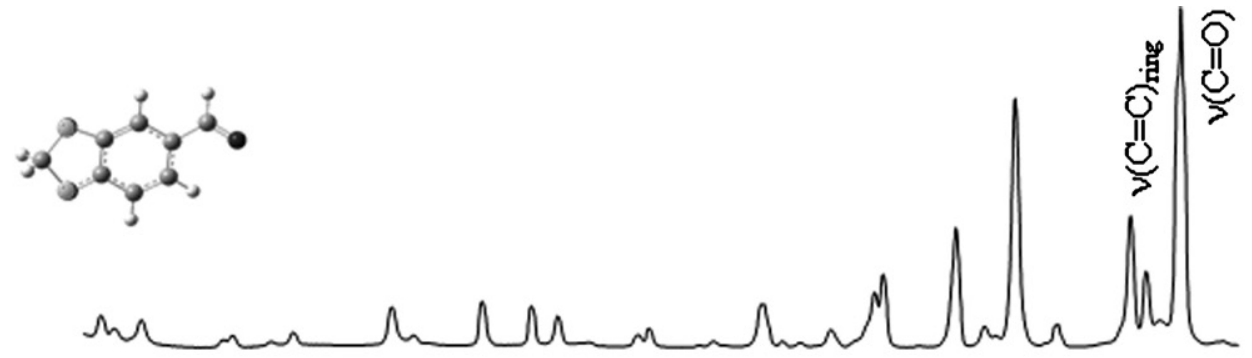

(B)

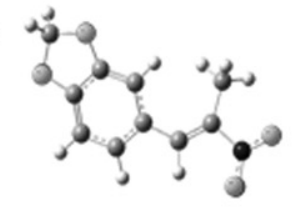

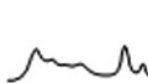<smiles>c1ccccc1</smiles><smiles>[AlH]C1CCCCC1</smiles><smiles>COCCOCCOCCO</smiles>

(C)

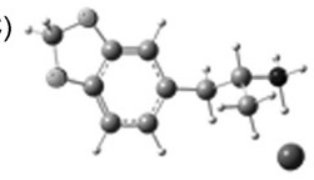

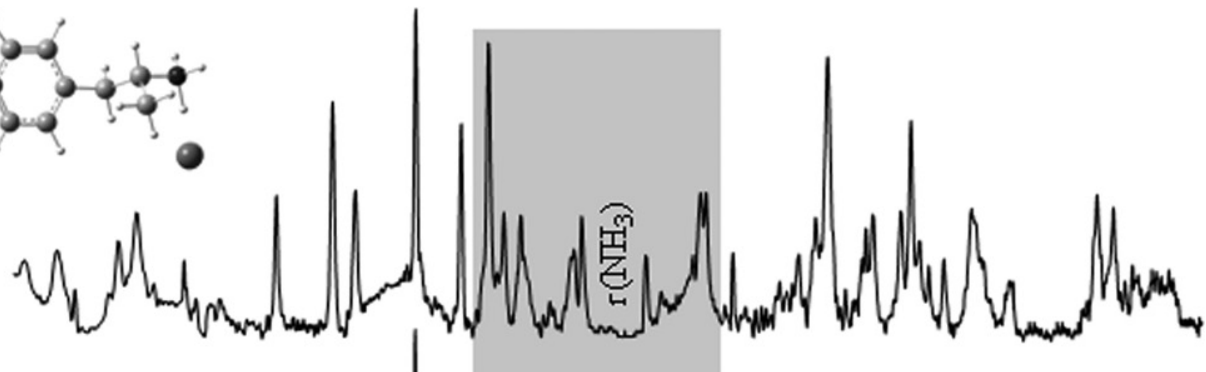

(D) +

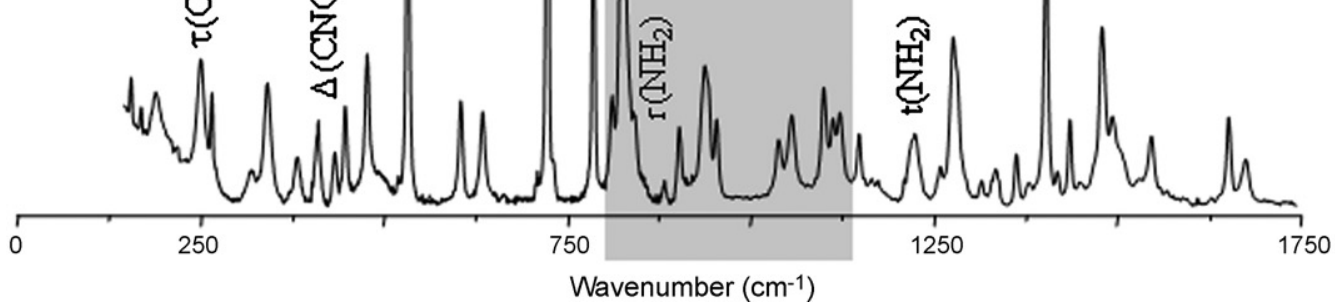

Fig. 6. Experimental Raman spectra $\left(100-1750 \mathrm{~cm}^{-1}\right.$, solid state, at $\left.25^{\circ} \mathrm{C}\right)$ for piperonal (A), 3,4-methylenedioxy- $\beta$-methyl- $\beta$-nitrostyrene (B), 3,4methylenedioxyamphetamine hydrochloride (MDA) (C), 3,4-methylenedioxymethamphetamine hydrochloride (MDMA) (D). ( $\delta$ : in-plane deformation; $\Delta$ : in-plane deformation of skeleton atoms; $v$ : stretching; $v_{\mathrm{s}}$ : symmetric stretching; $v_{\mathrm{as}}$ : antisymmetric stretching; r: rocking; t: twisting; $\tau$ : torsion. Atoms are represented as in Fig. 5. The shaded area is expanded in Fig. 7.)

methylenedioxy- $\beta$-methyl- $\beta$-nitrostyrene, through the signals at $1445 \mathrm{~cm}^{-1}$ (aldehyde deformation, $\delta(\mathrm{CH})$ ) and $1647 \mathrm{~cm}^{-1}$ (chain $\mathrm{C}=\mathrm{C}$ stretching, $v(\mathrm{C}=\mathrm{C})$ ) - typical of piperonal - and at $1316 \mathrm{~cm}^{-1}$ (symmetric stretching of the nitro group, $v_{\mathrm{S}}\left(\mathrm{NO}_{2}\right)$ ) and $1672 \mathrm{~cm}^{-1}$ (carbonyl stretching, $v(\mathrm{C}=\mathrm{O})$ ) - characteristic of 3,4-methylenedioxy- $\beta$-methyl- $\beta$-nitrostyrene (Fig. 6).

This study is, to the authors' knowledge, the first attempt to perform a complete Raman spectral assignment of these amphetamine-like systems, based on a structural analysis carried out by theoretical methods. It follows a similar conformational analysis performed for $\beta$-methyl- $\beta$-nitrostyrenes [42], which are synthetic precursors of several amphetamines. These compounds can be detected as impurities or side-products in illicitly produced MDMA [21,53], which are likely to lead to severe adverse effects when contaminated with such products. 


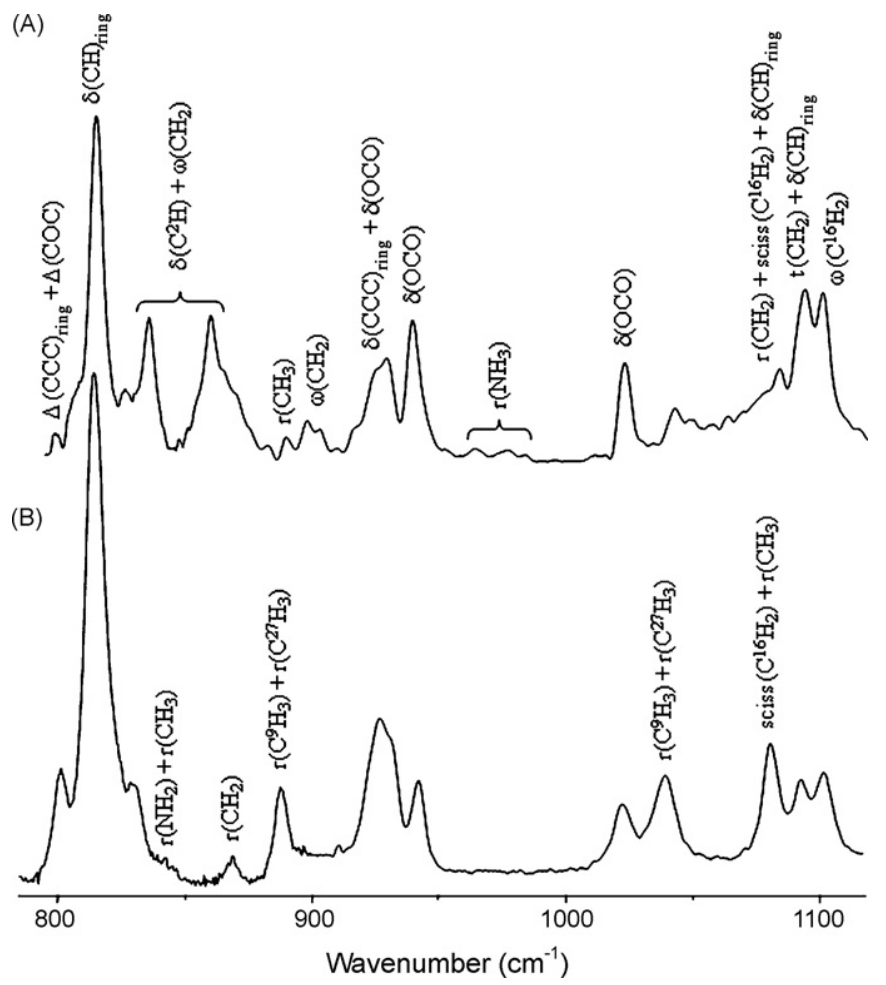

Fig. 7. Experimental Raman spectra $\left(780-1120 \mathrm{~cm}^{-1}\right.$, solid state, at $\left.25^{\circ} \mathrm{C}\right)$ for MDA (A) and "ecstasy" (B) hydrochlorides. (Atoms are numbered according to Fig. 5. $\delta$ : in-plane deformation; $\gamma$ : out-of-plane deformation; r: rocking; $\omega$ : wagging; sciss: scissoring; t: twisting.)

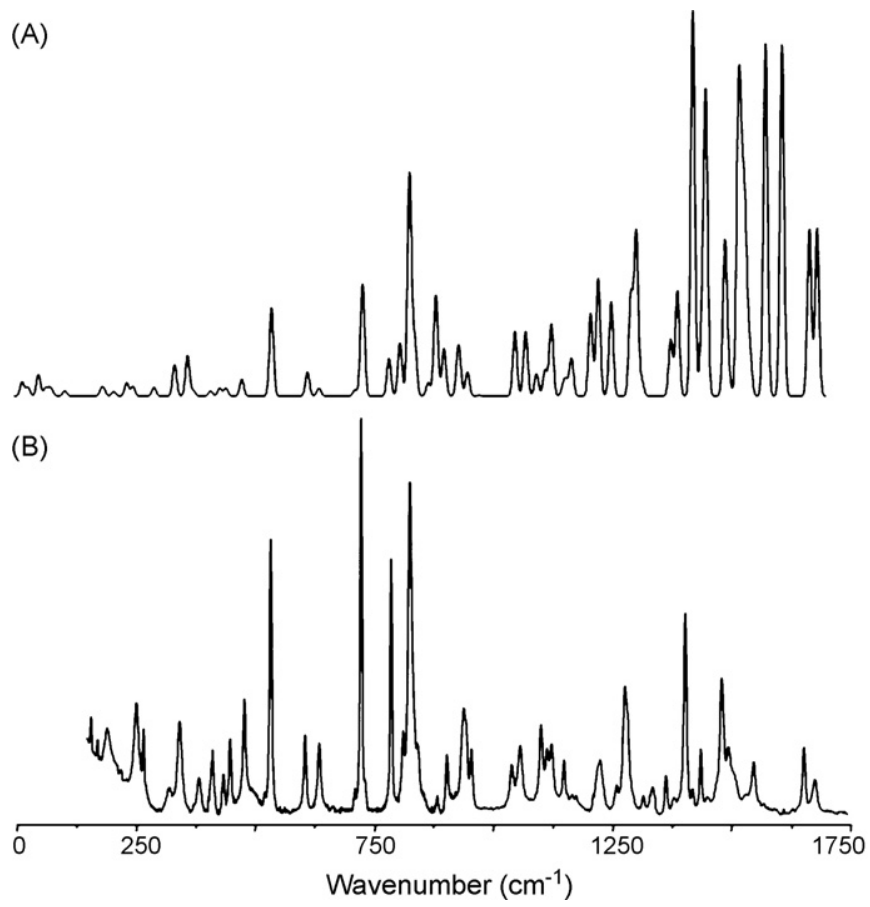

Fig. 8. Calculated (A) vs. experimental (B) Raman spectra $\left(0-1750 \mathrm{~cm}^{-1}\right)$ for 3,4-methylenedioxymethamphetamine hydrochloride.
Table 2

Selected experimental (solid state) and calculated (B3LYP/6-31G*) Raman wavenumbers $\left(\mathrm{cm}^{-1}\right)$ for the most stable conformer of "ecstasy" (MDMA)

\begin{tabular}{|c|c|c|}
\hline Experimental & Calculated $^{\mathrm{a}}$ & Approximate description $^{\mathrm{b}}$ \\
\hline & 3339 & $v\left(\mathrm{NH}_{2}\right)$ \\
\hline & 3105 & $v\left(\mathrm{C}^{5} \mathrm{H}\right)$ \\
\hline \multirow[t]{2}{*}{3083} & 3082 & $v\left(\mathrm{C}^{2} \mathrm{H}\right)$ \\
\hline & 3079 & $v\left(\mathrm{C}^{5} \mathrm{H}\right)+v\left(\mathrm{C}^{6} \mathrm{H}\right)$ \\
\hline 3060 & 3072 & $v\left(\mathrm{C}^{27} \mathrm{H}_{3}\right)$ \\
\hline 3054 & 3044 & $v\left(\mathrm{C}^{27} \mathrm{H}_{3}\right)$ \\
\hline 3023 & 3038 & $v\left(\mathrm{C}^{9} \mathrm{H}_{3}\right)$ \\
\hline 2994 & 2997 & $v\left(\mathrm{C}^{16} \mathrm{H}_{2}\right)$ \\
\hline 2981 & 2992 & $v\left(\mathrm{C}^{7} \mathrm{H}_{2}\right)$ \\
\hline 1634 & & $v(\mathrm{CC})_{\text {ring }}$ \\
\hline \multirow[t]{2}{*}{1611} & 1617 & $v(\mathrm{CC})_{\text {ring }}$ \\
\hline & 1546 & $\omega\left(\mathrm{NH}_{2}\right)$ \\
\hline \multirow[t]{2}{*}{1516} & 1514 & $\mathrm{t}\left(\mathrm{C}^{16} \mathrm{H}_{2}\right)$ \\
\hline & 1512 & $\mathrm{r}\left(\mathrm{NH}_{2}\right)$ \\
\hline 1459 & 1458 & $\mathrm{r}\left(\mathrm{C}^{27} \mathrm{H}_{3}\right)+\mathrm{r}\left(\mathrm{C}^{9} \mathrm{H}_{3}\right)+\mathrm{t}\left(\mathrm{C}^{7} \mathrm{H}_{2}\right)$ \\
\hline 1443 & 1440 & $\mathrm{r}\left(\mathrm{C}^{27} \mathrm{H}_{3}\right)+\operatorname{sciss}\left(\mathrm{NH}_{2}\right)$ \\
\hline 1403 & 1395 & $\gamma\left(\mathrm{C}^{27} \mathrm{H}_{3}\right)+\gamma\left(\mathrm{C}^{9} \mathrm{H}_{3}\right)+\operatorname{sciss}\left(\mathrm{C}^{16} \mathrm{H}_{2}\right)+\mathrm{r}\left(\mathrm{NH}_{2}\right)$ \\
\hline 1371 & 1367 & $\mathrm{t}\left(\mathrm{C}^{7} \mathrm{H}_{2}\right)$ \\
\hline 1249 & 1243 & $\omega\left(\mathrm{CH}_{2}\right)+\delta\left(\mathrm{C}^{8} \mathrm{H}\right)+\mathrm{t}\left(\mathrm{NH}_{2}\right)$ \\
\hline 1199 & 1204 & $\mathrm{t}\left(\mathrm{CH}_{2}\right)+\mathrm{r}\left(\mathrm{NH}_{2}\right)$ \\
\hline 1196 & 1178 & $\mathrm{r}\left(\mathrm{C}^{16} \mathrm{H}_{2}\right)$ \\
\hline 1102 & 1108 & $\omega\left(\mathrm{C}^{16} \mathrm{H}_{2}\right)$ \\
\hline 1094 & 1095 & $\mathrm{t}\left(\mathrm{CH}_{2}\right)+\delta(\mathrm{CH})_{\text {ring }}$ \\
\hline 1081 & 1084 & $\operatorname{sciss}\left(\mathrm{C}^{16} \mathrm{H}_{2}\right)+\mathrm{r}\left(\mathrm{C}^{27} \mathrm{H}_{3}\right)$ \\
\hline 1040 & 1054 & $\mathrm{r}\left(\mathrm{C}^{9} \mathrm{H}_{3}\right)+\mathrm{r}\left(\mathrm{C}^{27} \mathrm{H}_{3}\right)$ \\
\hline 1023 & 1030 & $\delta(\mathrm{OCO})$ \\
\hline 931 & 939 & $\delta(\mathrm{OCO})$ \\
\hline 927 & 916 & $\delta(\mathrm{OCO})$ \\
\hline 888 & 896 & $\mathrm{r}\left(\mathrm{CH}_{3}\right)+\mathrm{r}\left(\mathrm{CH}_{2}\right)+\mathrm{r}\left(\mathrm{NH}_{2}\right)+\delta\left(\mathrm{C}^{5} \mathrm{H}\right)+\delta\left(\mathrm{C}^{6} \mathrm{H}\right)$ \\
\hline 869 & 868 & $\mathrm{r}\left(\mathrm{NH}_{2}\right)$ \\
\hline 855 & 852 & $\mathrm{r}\left(\mathrm{CH}_{3}\right)+\mathrm{r}\left(\mathrm{NH}_{2}\right)$ \\
\hline 829 & 837 & $\delta\left(\mathrm{C}^{2} \mathrm{H}\right)$ \\
\hline 814 & 810 & $\delta\left(\mathrm{C}^{8} \mathrm{H}\right)$ \\
\hline 801 & 780 & $\delta(\mathrm{CH})_{\text {ring }}$ \\
\hline 777 & 758 & $v(\mathrm{C}=\mathrm{C})+v(\mathrm{CO})$ \\
\hline 725 & 706 & $v(\mathrm{CO})_{\text {ring }}$ \\
\hline 717 & 690 & $v(\mathrm{C}=\mathrm{C})$ \\
\hline 633 & 617 & $\Delta(\mathrm{CCC})_{\text {ring }}$ \\
\hline 606 & 594 & $\Delta(\mathrm{CCC})_{\text {ring }}$ \\
\hline 535 & 522 & $\Delta(\mathrm{CCC})_{\text {ring }}$ \\
\hline 479 & 481 & $\Gamma(\mathrm{CCC})+\Gamma(\mathrm{CCN})$ \\
\hline 449 & 448 & $\Gamma(\mathrm{COC})+\Gamma(\mathrm{CCC})+\Gamma(\mathrm{CCN})$ \\
\hline 411 & 416 & $\Gamma(\mathrm{COC})+\Gamma(\mathrm{CCC})+\Gamma(\mathrm{CCN})$ \\
\hline 381 & 380 & $\Gamma(\mathrm{COC})+\Gamma(\mathrm{CCC})$ \\
\hline 341 & 368 & $\Gamma(\mathrm{COC})+\Gamma\left(\mathrm{C}^{8} \mathrm{NC}^{27}\right)$ \\
\hline 267 & 254 & $\tau\left(\mathrm{C}^{9} \mathrm{H}_{3}\right)$ \\
\hline \multirow[t]{2}{*}{252} & 241 & $\tau\left(\mathrm{C}^{9} \mathrm{H}_{3}\right)+\Gamma(\mathrm{COC})$ \\
\hline & 214 & $\tau\left(\mathrm{C}^{9} \mathrm{H}_{3}\right)$ \\
\hline 193 & 193 & $\tau\left(\mathrm{C}^{27} \mathrm{H}_{3}\right)$ \\
\hline
\end{tabular}

a Wavenumbers above $400 \mathrm{~cm}^{-1}$ are scaled by a factor of $0.9614^{\mathrm{P} 6}$.

b Atoms are labeled according to Fig. $5 ; \delta$ : in-plane deformation; $\gamma$ : out-ofplane deformation; $\Delta$ : in-plane deformation of skeleton atoms; $\Gamma$ : out-of-plane deformation of skeleton atoms; $v$ : stretching; $v_{\mathrm{s}}$ : symmetric stretching; $v_{\mathrm{as}}$ : antisymmetric stretching; r: rocking; sciss: scissoring; t: twisting; $\tau$ : torsion; $\omega$ : wagging.

\section{Conclusions}

The results of this work evidence a reliable interplay between different areas of research (synthesis, electrochemistry and spectroscopy, coupled with DFT calculations) which all together 
allow an insight into the physicochemical properties of a drug of abuse (MDMA) and its synthetic impurities, obtaining valuable information for forensic or toxicological studies.

The development of new synthetic strategies for $\mathrm{N}$ methylation is of the utmost importance, both chemically and toxicologically. In fact, the pharmacological and toxicological profile of a drug is often a consequence of its metabolism, being $\mathrm{N}$-methylation one of the most important pathways. For instance, $\mathrm{N}$-methylated metabolites of amphetamine-like drugs of abuse (e.g. 3,4-dihydroxymethamphetamine) were found to be important to understand the toxicological profile of "ecstasy", at a molecular level [54,55].

In the present work, along with the development of synthetic strategies of $\mathrm{N}$-methylation the characterisation of the compounds was performed by electrochemical assays, as well as by Raman spectroscopy experiments and quantum mechanical (DFT) calculations. From the voltammetric results for MDMA, it was verified that the main anodic waves of the oxidation profile are associated with the aromatic moiety and the secondary amine group. A similar oxidative pattern was found for "ecstasy" synthetic impurities.

The vibrational (Raman) spectra, interpreted in the light of DFT calculations, allowed a rapid and unequivocal identification of the compounds investigated, which is of the utmost relevance for clinical, forensic and toxicological purposes. Raman spectroscopy has lately been shown to be a valuable tool for an unambiguous detection of amphetamine-like products [14,17]. Actually, this technique provides a spectral fingerprint of the compounds tested and can thus be used to identify even chemically similar intermediates, as well as to trace back the precursor materials and the synthetic pathways employed in the preparation of the samples. In a near future, one will hopefully be able to rely on a Raman database for both forensic and toxicological studies.

\section{Acknowledgements}

NM acknowledges financial support from FCT, PhD fellowship PRAXIS XXI/BD/18520/98, I\&D no. 226/94 and POCTI (QCA III). RC also acknowledges financial support from FCT, PhD fellowship SFRH/BD/16520/2004.

\section{References}

[1] D.E. Nichols, A.J. Hoffman, R. Oberlender, P. Jacob, A.T. Shulgin, J. Med. Chem. 29 (1986) 2009.

[2] D.E. Nichols, J. Psychoactive Drugs 18 (1986) 305.

[3] D.L. Martinez-Price, K. Krebs-Thomson, M.A. Geyer, Addict. Res. Theory 10 (2002) 43.

[4] K.M. Hegadoren, G.B. Baker, M. Bourin, Neurosci. Biobehav. Rev. 23 (1999) 539.

[5] G.A. Ricaurte, A.L. Martello, J.L. Katz, M.B. Martello, J. Pharmacol. Exp. Ther. 261 (1992) 616.

[6] U.D. McCann, V. Eligulashvili, G.A. Ricaurte, Neuropsychobiology 42 (2000) 11

[7] R.L. Fitzgerald, R.V. Blanke, J.A. Rosecrans, R.A. Glennon, Life Sci. 45 (1989) 295.

[8] K.-P. Kreth, K.-A. Kovar, M. Schwab, U.M. Zanger, Biochem. Pharmacol. 59 (2000) 1563
[9] A.P. Kulkarni, Curr. Pharm. Des. 7 (2001) 833.

[10] T.A. Dal Cason, J. Forensic Sci. 35 (1990) 675.

[11] M.A. Parker, D. Marona-Lewicka, D. Kurrasch, A.T. Shulgin, D.E. Nichols, J. Med. Chem. 41 (1998) 1001.

[12] M. Swist, J. Wilamowski, A. Parczewski, Forensic Sci. Int. 152 (2005) 175.

[13] H.H. Maurer, J. Bickeboeller-Friedrich, T. Kraemer, F.T. Peters, Toxicol. Lett. 112-113 (2000) 133.

[14] S.E.J. Bell, D.T. Burns, A.C. Dennis, J.S. Speers, Analyst 125 (2000) 541.

[15] S.E.J. Bell, D.T. Burns, A.C. Dennis, L.J. Matchett, J.S. Speers, Analyst 125 (2000) 1811.

[16] B. Sägmüller, B. Schwarze, G. Brehm, S. Schneider, Analyst 126 (2001) 2066.

[17] K. Faulds, W.E. Smith, D. Graham, R.J. Lacey, Analyst 127 (2002) 282.

[18] S.E.J. Bell, L.J. Barrett, D.T. Burns, A.C. Dennis, J.S. Speers, Analyst 128 (2003) 1331.

[19] B. Sägmüller, B. Schwarze, G. Brehm, G. Trachta, S. Schneider, J. Mol. Struct. 661-662 (2003) 279.

[20] P. Gimeno, F. Besacier, H. Chaudron-Thozet, Forensic Sci. Int. 132 (2003) 182.

[21] N.N. Daéid, R.J.H. Waddell, Talanta 67 (2005) 280.

[22] M.J. Frisch, et al., Gaussian 98, Revision A.9, Gaussian Inc., Pittsburgh, PA, USA, 1998.

[23] C. Lee, W. Yang, R.G. Parr, Phys. Rev. B37 (1988) 785.

[24] B. Miehlich, A. Savin, H. Stoll, H. Preuss, Chem. Phys. Lett. 157 (1989) 200.

[25] A.D. Becke, Phys. Rev. A38 (1988) 3098.

[26] A.D. Becke, J. Chem. Phys. 98 (1993) 5648.

[27] P.C. Hariharan, J.A. Pople, Theor. Chim. Acta 28 (1973) 213.

[28] C. Peng, P.Y. Ayala, H.B. Schlegel, M.J. Frisch, J. Comp. Chem. 17 (1996) 49.

[29] A.P. Scott, L. Radom, J. Phys. Chem. 100 (1996) 16502.

[30] B.M. Sykes, G.J. Atwell, A. Hogg, W.R. Wilson, C.J. O'Connor, W.A. Denny, J. Med. Chem. 42 (1999) 346.

[31] E. Hammarberg, G. Nordvall, R. Leideborg, M. Nylöf, S. Hanson, L. Johansson, S.-O. Thorberg, B.-R. Tolf, E. Jerning, G.T. Svantesson, N. Mohell, C. Ahlgren, A. Westlind-Danielsson, I. Csöregh, R. Johansson, J. Med. Chem. 43 (2000) 2837.

[32] C.G. Chavdarian, D. Karashima, N. Castagnoli, H.K. Hundley, J. Med. Chem. 21 (1978) 548.

[33] A.F. Abdel-Magid, K.G. Carson, B.D. Harris, C.A. Maryanoff, R.D. Shah, J. Org. Chem. 61 (1996) 3849.

[34] A. Adejare, F. Gusovsky, W. Padgett, C.R. Creveling, J.W. Daly, K.L. Kirk, J. Med. Chem. 31 (1988) 1972.

[35] S. Lu, B. Herbert, G. Haufe, K.W. Laue, W.L. Padgett, O. Oshunleti, J.W. Daly, K.L. Kirk, J. Med. Chem. 43 (2000) 1611.

[36] M. Masui, H. Sayo, Y. Tsuda, J. Chem. Soc. B (1968) 973.

[37] J.M.P.J. Garrido, C. Delerue-Matos, F. Borges, T.R.A. Macedo, A.M. Oliveira-Brett, Electroanalysis 16 (2004) 1497.

[38] M. Masui, H. Sayo, J. Chem. Soc. B (1971) 1593.

[39] A. Adenier, M.M. Chehimi, I. Gallardo, J. Pinson, N. Vilà, Langmuir 20 (2004) 8243

[40] J.A. Squella, B.K. Cassels, M. Arata, M.P. Bavestrello, L.J. Nunez-Vergara, Talanta 40 (1993) 1379.

[41] J.M.P.J. Garrido, C. Delerue-Matos, F. Borges, T.R.A. Macedo, A.M. Oliveira-Brett, Electroanalysis 16 (2004) 1427.

[42] N. Milhazes, F. Borges, R. Calheiros, M.P.M. Marques, Analyst 129 (2004) 1106.

[43] R.E. Clavijo, R. Araya-Maturana, B.K. Cassels, B. Weiss-López, Spectrochim. Acta A 50 (1994) 2105.

[44] A. By, G. Neville, H.F. Shurvell, J. Forensic Sci. 37 (1992) 503.

[45] R. Calheiros, N. Milhazes, F. Borges, M.P.M. Marques, J. Mol. Struct. 692 (2004) 91.

[46] S.J. Greaves, W.P. Griffith, Spectrochim. Acta A 47 (1991) 133.

[47] F.J. Ramírez, J.T. López Navarrete, Vib. Spectrosc. 4 (1993) 321.

[48] R. Hargitai, P.G. Szalay, G. Pongor, G. Fogarasi, J. Mol. Struct. (THEOCHEM) 306 (1994) 293. 
[49] Y. Haas, S. Kendler, E. Zingher, H. Zuckermann, S. Zilberg, J. Chem. Phys. 103 (1995) 37.

[50] M. Gerhards, W. Perl, S. Schumm, U. Henrichs, C. Jacoby, K. Kleinermanns, J. Chem. Phys. 104 (1996) 9362.

[51] E. Van Besien, M.P.M. Marques, J. Mol. Struct. (THEOCHEM) 625 (2003) 265.

[52] S.M. Fiuza, E. Van Besien, N. Milhazes, F. Borges, M.P.M. Marques, J. Mol. Struct. 693 (2004) 103
[53] P. Gimeno, F. Besacier, M. Bottex, L. Dujourdy, H. Chaudron-Thozet, Forensic Sci. Int. 155 (2005) 141.

[54] M. Carvalho, F. Remião, N. Milhazes, F. Borges, E. Fernandes, M.C. Monteiro, M.J. Gonçalves, V. Seabra, F. Amado, F. Carvalho, M.L. Bastos, Chem. Res. Toxicol. 17 (2004) 623.

[55] M. Carvalho, N. Milhazes, F. Remião, F. Borges, E. Fernandes, F. Amado, T.J. Monks, F. Carvalho, M.L. Bastos, Arch. Toxicol. 78 (2004) 16. 